\title{
Assessing vulnerability and adaptation strategy of the cyclone affected coastal area of Bangladesh
}

\author{
Md. Mizanoor Rahman ${ }^{1 *} \mathbb{D}$, Md. Alamgir Hossain ${ }^{2}$, Md. Rayhan Ali ${ }^{3}$, Zihad Ahmed ${ }^{1}$ and \\ A. H. M. Hedayutul Islam
}

\begin{abstract}
Bangladesh is a land of natural calamities. Due to locational disadvantages, especially being situated at the tip of the funnel-shaped Bay of Bengal on the south and at the foot of Himalayas on the north, every year it experiences a number of different types of natural calamities, such as flood, cyclone, river bank erosion, drought etc. As a result of climate change events, an increasing trend in frequency has been observed in recent time. Spatial distribution of natural calamities portraits northern part as prone to flood, western part to drought, eastern part (basically hilly region) to flash flood and southern part to cyclone. The Southern part, especially the coastal belt of the country is the worst affected area to cyclones and their ultimate effects. Among these cyclones, Aila was a severe one that tore through the area in 2009 affecting the livelihood of the inhabitants. This study is an effort to discuss the inhabitants' vulnerability and their adaptation strategies to economic changes caused by Aila, such as occupation, income, expenditure capacity, savings, housing structures, general and agricultural land use etc. For the study required data has been collected from both primary and secondary sources. Primary data have been collected through questionnaire survey and group discussion while secondary data, especially satellite images have been collected from Google Earth. Then different softwares like SPSS have been used for analysis and graphic presentation of the collected primary data, and ERDAS IMAGINE and ArcGIS have been used for mapping analysis and presentation. The research findings indicate that because of the cyclone Aila, economy of the area has taken downturn. Most of the people were engaged in agriculture allied activities, but after Aila, agricultural land had been converted into aquaculture. Consequently, people have switched to occupations with lesser earnings, such as daily labour, rickshaw puller, brick field worker etc. As a result, people had to reduce all sorts of daily consumptions to cope up with the changing situation. The Governmental Organisations and the Non-Governmental Organisations extended little help to rebuild houses, embankment, road, reforestation etc. but not towards any income generates activities. So, the livelihood of the people is still vulnerable in terms of economy, and attention of the responsible authorities needs to be drawn to create income generating activities to recover the vulnerable situation in the study area.
\end{abstract}

Keywords: Cyclone Aila, Economic transformation, Land use change, Vulnerability, Adaptation

\footnotetext{
*Correspondence: mizangeo@gmail.com

1 Department of Geography and Environmental Studies, University

of Rajshahi, Rajshahi, Bangladesh

Full list of author information is available at the end of the article
}

\section{Background}

Climate change, rapid urbanization and infrastructure development trends push the global community toward higher exposure to natural hazards (Parajuli 2020). Bangladesh is at grave risk and is extremely vulnerable to climate change affiliated events, basically various natural disasters such as cyclones, floods, tidal 
surges, riverbank and coastal erosion, drought etc. and currently is ranked as the most climatically vulnerable country in the world (IPCC 2007). The country is trapped between the Himalayas on the north and the Bay of Bengal to the south with $711 \mathrm{~km}$ long coastline (CDP 2006). Geographical location and funnel-shaped coastline have increased susceptibility of the country to frequent extreme climatic events, and has caused disasters of one kind or another such as tropical cyclones, storm surges, coastal erosion, floods, and droughts in regular basis. And among them, flood and cyclone are frequent and threaten the livelihood, property and jeopardize the development activities (Ali 1999). Evidences indicate that if world's tropical cyclones with death tolls in excess of 5000 are considered; 16 out of 35 such disasters have occurred in this country. About $53 \%$ of the world deaths from these cyclones have occurred in this country (Damen et al. 2015). On an average, every three years, Bangladesh experiences a severe cyclone strike (DDM 2009). Since 1970, a number of cyclones have hit the southern part of the country, and among them, eleven cyclones such as November 1970 (Bhola Cyclone), April 1991, May 1997, September 1997, May 1998, November 2007 (Sidar) and May 2009 (Aila), May 2013 (Mahasen), May 2016 (Roanu), May 2019 (Fani) and lastly May 2020 (Amphan) have been documented as severe in magnitude. But considering the damage to properties and the long term effects, the Aila attained the highest magnitude. The cyclone Aila tore through the southern part of Bangladesh in May 2009 killing 300 people, and destroyed 2500 miles of roads and embankments. Almost all the dwellers of the affected area have lost their livelihood, where $80 \%$ of the population depended on agriculture and $20 \%$ on fish firming, wage labour and other small business. Aid organisations are reporting that yet 200,000 people are still living in inhuman conditions or have been displaced. According to United Nations (UN) Office for the Coordination of Humanitarian Affairs (OCHA 2009) report, approximately 350,000 people were displaced and unable to return to affected villages. Notable work has begun to acclimatise the damaged embankment areas, which are flooded twice daily that contaminates fresh water with salinity and makes farming difficult due to saline water. Families in these areas depend on emergency food and water distribution. Still now, most of the people are homeless and have lost their jobs, and their livelihood has become vulnerable as the economic condition of the area has been transformed. Such devastating damage can be seen ten years later when cyclone Amphan hit the area in 2020 while people were still trying to recover from their loss caused by Aila.

\section{Objectives of the study}

The general objective of the present study is to discuss the changing economy and livelihood pattern due to Aila, and how the dwellers and different GOs and NGOs are trying to recover the situation. On the basis of analysis, the study has presented recommendations and strategies in order to improve preventive measure and enhance adaptive capacity of the victims.

The specific objectives are as follows-

a. To discuss the changing economic circumstances in the context of vulnerability that occurred due to the Aila in the study area.

b. To discuss the role of stakeholders and organizations (both national and international) in recovering the situation; and on the basis of the result, recommend a strategy for rapid improvement of the situation.

\section{Literature background of vulnerability and adaptation \\ Vulnerability}

Over the past few years, the geographic understanding of natural hazards shifted from a hazard-centered approachto a vulnerability-centered approach, integrating the social dimension of hazard. Such a diagnosis and evaluation of vulnerability presents advantages in terms of anticipating risk and mitigating its impacts (Durand et al. 2018). Vulnerability refers to the propensity of exposed elements such as human beings and their livelihoods to suffer damage and loss when impacted by single or diverse hazard events (UNDRO 1980; Timmerman 1981; Maskrey 1984; Cardona 1990; Liverman 1990; Cannon 2006; Blaikie et al. 1996; UNISDR 2004; Birkmann 2006b; Thywissen 2006). The Intergovernmental Panel on Climate Change (IPCC 2007) defines vulnerability as the extent to which a natural or social system is susceptible to sustaining damage from climate change. However, the level of vulnerability is determined by the adverse consequences that remain after the process of adaptation has taken place (Kelly and Adger 2000). McCarthy et al. (2001), Birkmann (2006a, b), Carreño et al. (2007), IPCC (2007) has mentioned that vulnerability originates depending on three factors, such as exposure, susceptibility/fragility and lack of resilience. Vulnerability is a function of the sensitivity of a system to which in climate and the ability to adapt the system to changes in climate. A better planning for vulnerability assessment due to climatic event can be formulated through the following three steps: 
- A sensitivity analysis of the systems associated with the planning areas;

- An evaluation of the adaptive capacity of the systems associated with each of these planning areas; and

- An assessment of how vulnerable the systems in the planning areas are to the effects of climate change.

Moreover, vulnerability is the highest where there is the greatest sensitivity to climate change and the least adaptability (Fig. 1).

\section{Measuring vulnerability}

Vulnerability can be measured in multiple ways.

Yohe et al. (2002) mentioned $\mathrm{V}=\mathrm{f}\{\mathrm{E}(\mathrm{AC}) ; \mathrm{S}(\mathrm{AC})\}$, where $\mathrm{V}$ is vulnerability, $\mathrm{E}$ is exposure, $\mathrm{S}$ is sensitivity, and $\mathrm{AC}$ is adaptive capacity.

Here, the vulnerability of a system is a function of its exposure and sensitivity, which in turn is a function of the system's adaptive capacity and resilience. The ability to measure vulnerability is increasingly being seen as a key step towards effective risk reduction and the promotion of a culture of disaster resilience.

Brien et al. (2004) and Kelly and Adger (2000) separate definitions of vulnerability into two categories. One is contextual or focal point approaches to assessing vulnerability focus on the context that creates vulnerability and view vulnerability as a consequence of social and institutional factors. Vulnerability is thus determined by interaction between social norms, political institution and resource endowments (Adger 2006). On the other hand, the End-point or outcome estimates of vulnerability define vulnerability as what is left after expected impacts and adaptation is accounted for, and can thus be seen as the net impact of climate change (Kelly and Adger 2000). Typically, for the latter category, impact scenarios and estimates of biophysical climate change impacts are studied in order to assess vulnerability. However, two approaches are more familiar to measure vulnerability.
The indicator approach The indicator approach aims to measure vulnerability to climate change through combining indicators of biophysical impacts (exposure) with indicators of socio-economic characteristics (sensitivity and adaptation) in an aggregate indicator of vulnerability (Gbetibouo et al. 2010). The approach has been used both at the global level (Brooks et al. 2005) and national and regional levels (Gbetibouo et al. 2010; Brien et al. 2004).

The econometric approach A second group of approaches, to measure vulnerability, use econometric analysis to estimate either expected poverty measures or expected utility measures of vulnerability to any climatic event. In general, both the vulnerability as expected poverty (VEP) and the vulnerability as low expected utility (VEU) approaches are based on calculating the probability that the individual or household's welfare falls below some benchmark level as the result of a shock or exposure to risk.

\section{Sensitivity}

Positive correlation can be found between sensitivity and vulnerability. If sensitivity rises for a certain calamity, the vulnerability also rises. Sensitivity is the degree to which a built, natural or human system is directly or indirectly affected by changes in climate conditions (e.g., temperature and precipitation) or specific climate change impacts (e.g., sea level rise, increased water surface temperature). If a system is likely to be affected as a result of projected climate change, it should be considered sensitive to climate change (Centre for Science in the Earth System 2007).

\section{Adaptation}

In the climate change research very often resilience and adaptation are used as synonyms. Adaptation of societies and activities is an excellent umbrella concept for those factors that mediate between geophysical conditions and events, on the one hand; and human abilities to cope with, take advantage of, or adapt to those

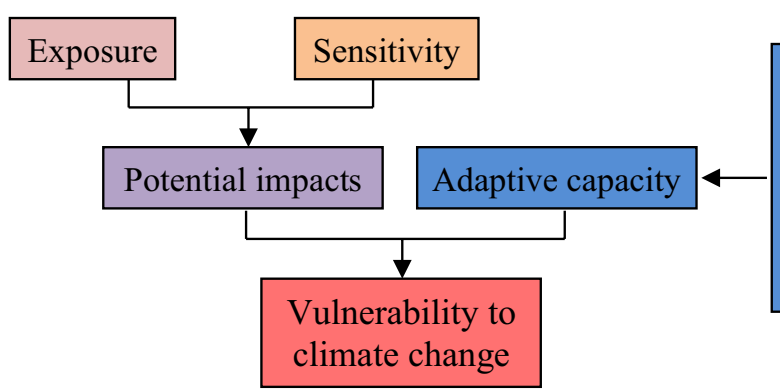

- Economic wealth

- Technology and infrastructure

- Information, knowledge and skills

- Institutions

- Equity

- Social capital

Fig. 1 Conceptualisation of vulnerability to climate change in the IPCC Third Assessment Report 
conditions and events, on the other hand (Rayner and Elizabeth 2000). Adaptation is a composite concept, incorporating environmental, social, economic, political, demographic, cultural, gender and psychological factors, in describing the capacity to recover and survive, to change and grow. For instance, Yohe et al. (2002) identified eight generalized "determinants of adaptive capacity," many of which are societal in character. Whereas the vulnerability-resilience indicators model (VRIM) identifies 17 factors that together assess the resilience of a society. The VRIM has been used to compare 160 countries, evaluate adaptive capacity at temperature increases of $1.5{ }^{\circ} \mathrm{C}$ and $4.5{ }^{\circ} \mathrm{C}$, analyze India and Indian states under current conditions and future scenarios, and examine resilience in Mexico and Mexican states. Again, Brooks et al. (2005) point out that the concept of adaptive capacity only makes sense in the context of what resources and systems would be affected by climate change. Adaptive capacity describes the ability of built, natural and human systems associated with a given planning area to accommodate changes in climate with minimum disruption or minimum additional coast. Adaptation can be spontaneous or planned, and can be carried out in response to or in anticipation of change in conditions (Watson et al. 1998). However, the coping processes are reflected in systems of resource use, including agriculture, water consumption, housing styles, settlement locations and the like. It is important to recognise that the coping process is dynamic; since the influences people and communities respond to, and their personal needs and wants, are constantly changing. Planned adaptation activities should always be undertaken in ways that reinforce coping processes (Hay and Mimora 2005).

The Government of Bangladesh has taken a 10 year programme (2009-2018) named Climate Change Action Plan to build the capacity and resilience of the country to meet the challenges of climate change. Keeping the needs of poor and vulnerable, including women and children in view, the programme comprises six pillars. They are:

- Food Security, Social Protection and Health

- Comprehensive Disaster Management

- Infrastructure

- Research and Knowledge Management

- Mitigation and Low Carbon Development

- Capacity Building and institutional Strengthening

Under these six themes, a number of programmes have been taken to address the problem related to the climate change impact. Among the programmes Research and Knowledge Management, Capacity Building, Infrastructure development like Embankment, Polder and Cyclone
Shelter building, invention of saline water tolerant varieties to ensure the food security.

\section{Materials and methods}

A rigorous literature review has been conducted in order to develop a detailed conceptual background on the methodology of the research. The cyclone Aila affected eleven districts in the southern Bangladesh. In the present study, one village, Patakhali, from Khulna district and two villages, Sora and Chakbara, from Satkhira district have been selected purposively, as these two districts were the most affected. Required data have been collected from both primary and secondary sources. Keeping in view of vulnerability and adaptation strategy perspective data on economic activities, data on income, expenditure, savings etc. have been collected through questionnaire survey and focus group discussion while other information have been collected from secondary source especially land use and land cover (LULC) information from satellite image processing. By using open source Landsat data integrated with geographic information system (GIS) technologies and other ancillary data, this study attempts to classify LULC and create land cover maps, enabling post-classification change detection analysis. For the study Landsat satellite images of 2004 and 2014 have been used to identify LULC change. The images of 2004 were $30 \mathrm{~m}$ resolution thematic mapper (TM) images acquired on November 4, 2004 and the images of 2014 were in $30 \mathrm{~m}$ resolution Landsat 8 image acquired on October 26, 2014. The source of those images was the Earth Explorer. ERDAS Imagine 2014 software has been used to process collected remotely sensed imageries, especially to classify LULC, change detection and spatial analysis. The purpose of the field work for this study is to observe the study area and collect the ground truth data for land cover classification by using maps and global positioning system (GPS). A total 40 sample points were selected for the whole stratum and those were classified into the forest, agricultural land, settlement, water bodies, aquaculture, and bare land. ArcGIS 9.3 software was used to process data in GIS operation. Besides, information related to role of organizations has been collected from several GOs and NGOs office through structured checklist. However, collected data were processed and analyzed using Statistical Package for the Social Sciences (SPSS) software.

\section{Result and discussion Vulnerability}

In the following section magnitude of the vulnerability has been discussed considering influencing factors, analysis of sensitivity and vulnerability to the cyclone Aila. 


\section{Influencing factors of vulnerability}

Wilbanks et al. (2007) noted that the two factors that contribute to vulnerability are largely determined by the development context which has a strong influence on households' income, education and access to information, on people's exposure to environmental hazards in their homes and workplaces and on the quality and extent of provision for infrastructure and services. Magnitude of vulnerability to cyclonic events depends on a number of factors including scale of cyclonic events, levels of economic status, control over assets, management and livelihood opportunities. Depending on type of factors, vulnerability can be varied, but those work together as an integrated approach (Fig. 2). The influencing factors are as follows.

Location Bangladesh is prone to natural calamities such as flood, river bank erosion, drought, cyclone etc. due to its locational exposure. In general, north-western part of it is exposed to drought, Brammaputtro-Jammuna-Meghna estuaries to riverbank erosion and flood, and coastal region to cyclonic events. The Bay of Bengal is considered one of the pertinent cyclonic events' breeding grounds of the world. Due to the effect of climate change, increase in sea surface temperature (SST) makes the area more suitable for cyclone formation. From life cycle of cyclone it can be seen that it generates from sea and ends at coast. Due to being close to the Bay of Bengal, the study area experiences number of cyclones each year and enhanced exposure to vulnerability (Fig. 3).
Physiography Geomorphologically, coastal region of Bangladesh is a low laying area situated at the southernmost part of the Ganges floodplain. Average elevation of this area is less than $1 \mathrm{~m}$ from mean sea level. At small scale, this elevation may vary from 0 to $0.5 \mathrm{~m}$ (Fig. $4 \mathrm{a}$ ). As a result, the study villages are susceptible to any high tide or any possible cyclonic surges those are just higher than $1 \mathrm{~m}$ (Fig. 4b). The area is enclosed by $4800 \mathrm{~km}$ coastal embankment to protect it from tidal and cyclonic surges. Most of the embankment was damaged either partially or fully by the cyclone Aila; as the height of the cyclone surges was more than $1.83 \mathrm{~m}$ and the embankment was too weak to hold against such a strong surge (Fig. 5). Observation during field survey shows most part of the area still now is flooded twice daily by the tide.

Distance from coast Cyclonic track analysis revealed that a cyclone can travel a hundred of kilometers even on land surface, but gradually loses its energy with time and distance covered after encroaching the coast. So, it is easily anticipated that the nearest area is more vulnerable to cyclonic affect than those from far. Study villages are situated within $70 \mathrm{~km}$ from the open sea coastline. On the basis of the magnitude of cyclonic events a hundred kilometers area can be severely affected. From analysis of satellite images it is found that average distance of Sora, Chakbara and Patakhali villages are 64.9, 65.49 and $60.86 \mathrm{~km}$ respectively from the coast of the Bay of Bengal, and they are very close to the coast to be affected severely even by a moderate cyclone (Table 1 ).

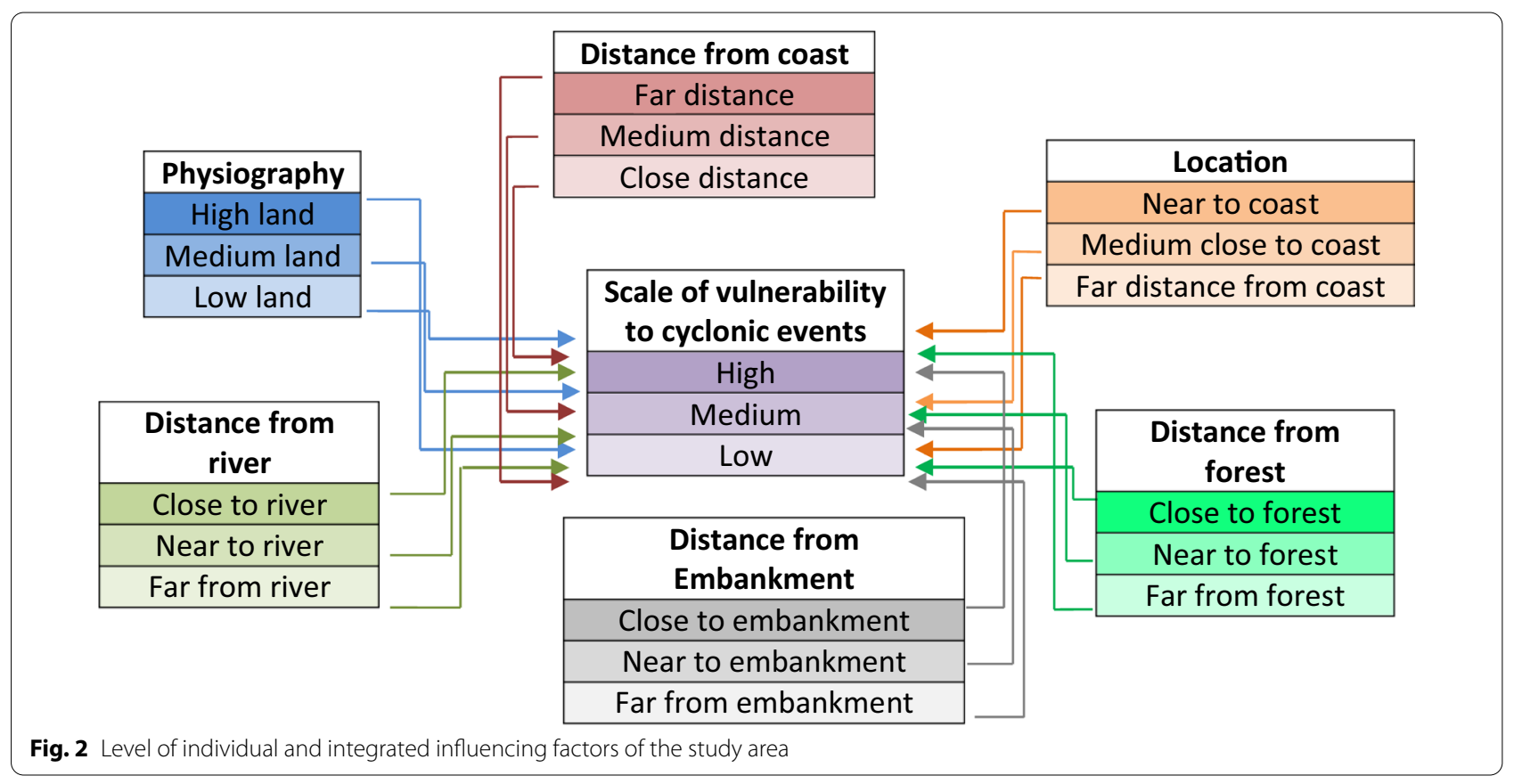



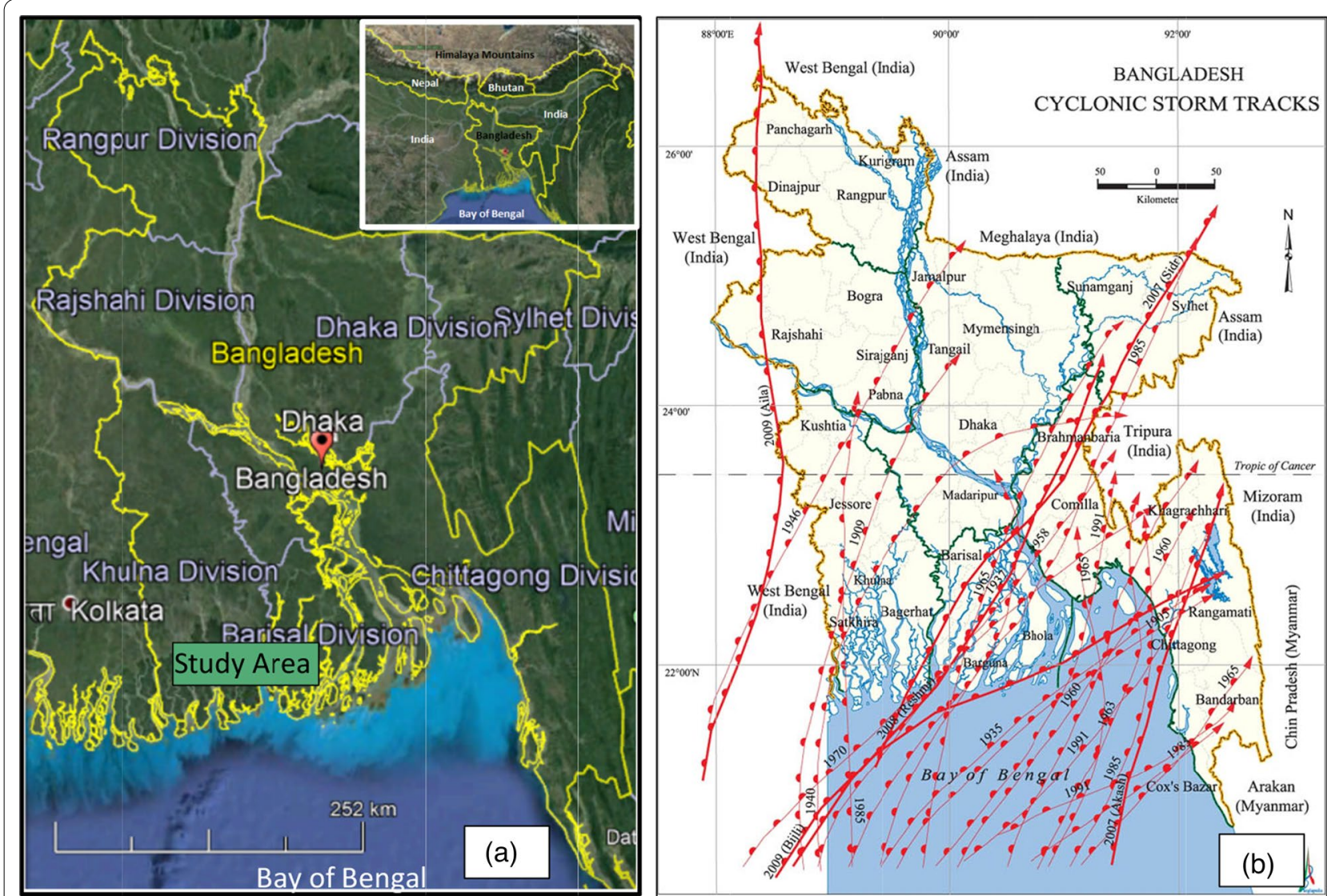

Fig. 3 a Location of study area in respect of Bangladesh and surrounding areas. b Cyclone track of Bangladesh. Source $\mathbf{a}$ Google Earth Pro, b Banglapedia

Distance from river River is another influencing factor on which magnitude of vulnerability to cyclone is mostly dependent. Because, the rivers are connected to the Bay of Bengal influenced by tides. Sora is bounded on the west and south by the Kholpetua River and Chakbara village is bounded on the west by the same river. But both of the villages are bounded on the far-east by the Kobotak River. On the other hand, Patakhali village is bounded on the far west and east by the Kobotak and the Rai River respectively. Thus, the rivers are sources of earning as well as food and have great impact on community livelihood. But simultaneously, the rivers make the villagers' livelihood vulnerable due to cyclonic surges when it overtops embankment and wash away houses, agricultural field, aquaculture, road, fishes etc. Survey result indicates that both Sora and Chakbara villages are situated on the bank of the Kholpetua River while Patakhali is little bit far from the rivers (Table 1). In consideration of location and distance from the river, Sora is more prone to be vulnerable than other two villages, again Chakbara more than Patakhali.
Distance from forest The mangrove forest, the Sunderbans, is situated alongside the coast of the Bay of Bengal, which is on the southern side of the study area, and it works as a natural barrier to cyclonic events. The Sunderbans, to some extent, helps the area to reduce the intensity of cyclones and its aftermath impact when the cross the area. The average distance of the Sunderbans from Sora is $2.19 \mathrm{~km}$, from Chakbara $4.96 \mathrm{~km}$ and from Patakhali $2.41 \mathrm{~km}$. It indicates that Sora is less prone to be vulnerable than other two villages.

Distance from embankment The average land elevation of the area, which is less than $0.50 \mathrm{~m}$ from MSL, is susceptible to any cyclonic surges as well as high tide. In order to protect these areas from tidal inundation and cyclonic surges, embankments have been built by the then East Pakistan Water and Power Development Authority (EPWAPDA) and WAPDA of Bangladesh during 19611978 under the Coastal Embankment Project (CEP). Sora and Chakbara are on the bank of Kholpetua river and the embankment is built alongside the river bank; but the 


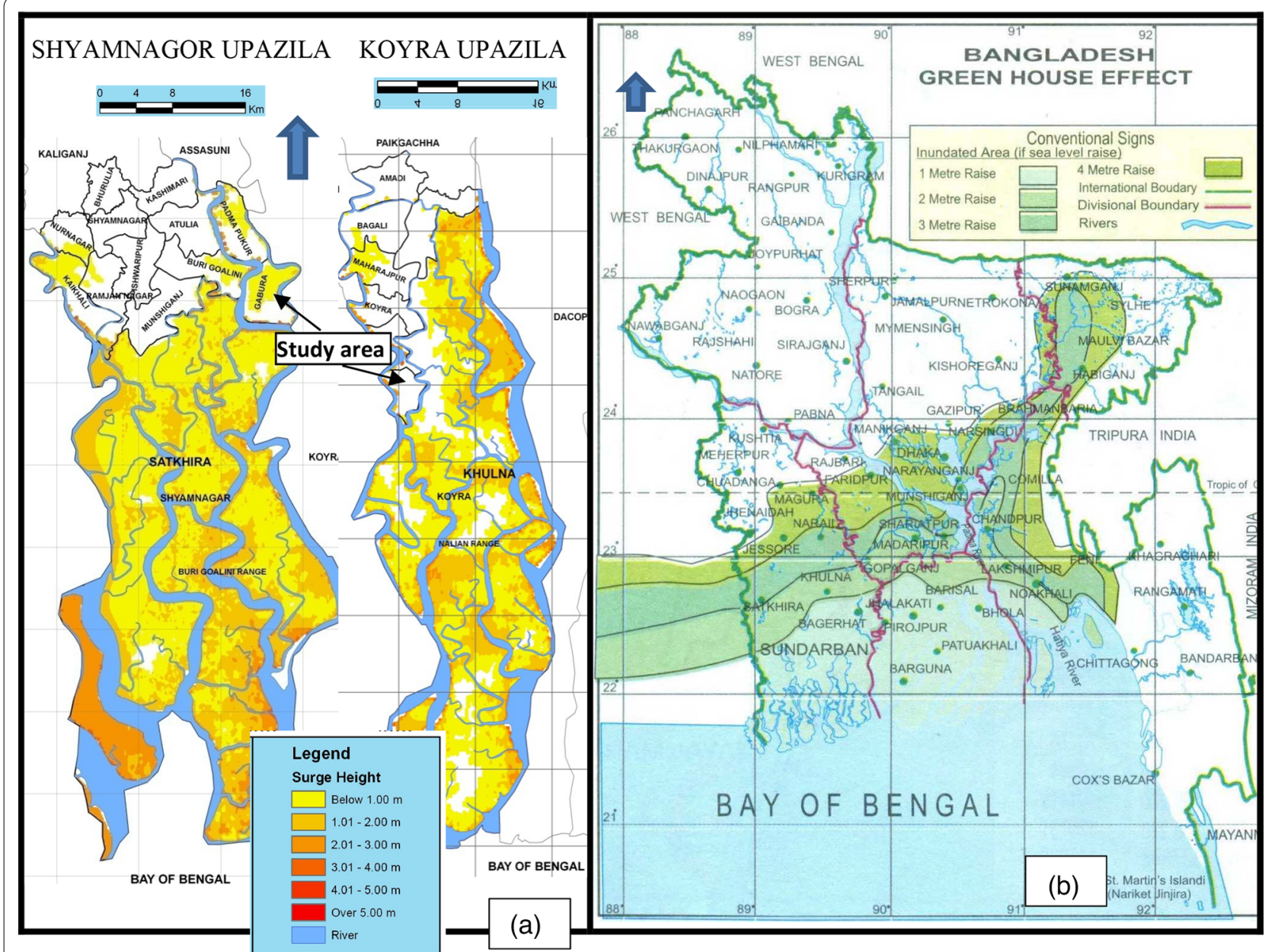

Fig. 4 a Elevation of study area from Mean Sea Level (MSL). $\mathbf{b}$ Inundated areas of Bangladesh if sea level rises. Sources a MoFDM DMRD CDMP, $\mathbf{b}$ Geo Consult 2004

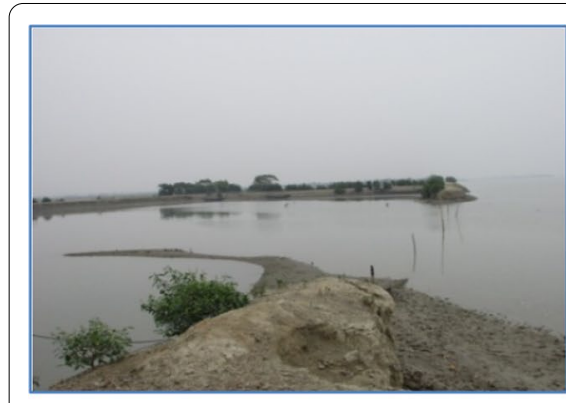

Sora

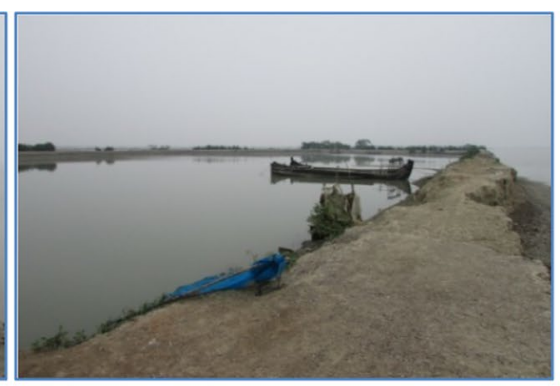

Chakbara

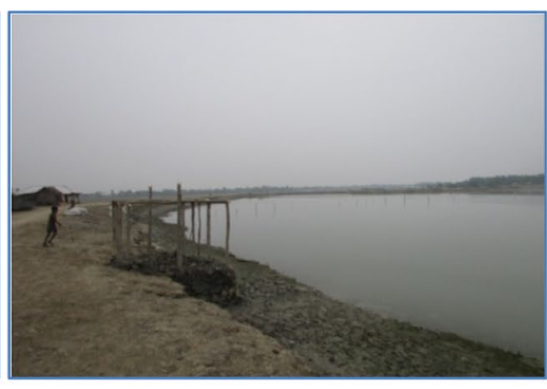

Patakhali

Fig. 5 Damaged embankment by the cyclone Aila of the study area

Patakhali village is away from the embankment of Kobotak river. At this juncture, Sora is more prone to be vulnerable than other two villages due to its long embankment alongside the river.
Connectivity Connectivity to the road is a vital factor for evacuation and rescue operation during disaster and post disaster relief operations. The improved road communication networks accelerate the rate of evacuation and rescue 
Table 1 Integrated impacts of the influencing factors of vulnerability in the study area

\begin{tabular}{|c|c|c|c|c|c|c|c|c|}
\hline \multirow[t]{2}{*}{ Influencing factors } & \multirow[t]{2}{*}{ Level } & \multicolumn{3}{|c|}{ Actual figure } & \multirow[t]{2}{*}{ Assigned points } & \multicolumn{3}{|c|}{ Obtained weight } \\
\hline & & Sora & Chakbara & Patakhali & & Sora & Chakbara & Patakhali \\
\hline \multirow[t]{3}{*}{ Physiography (General observation) } & High land & 0 & 0 & 0 & 1 & 2 & 2 & 3 \\
\hline & Medium land & $\sqrt{ }$ & $\sqrt{ }$ & 0 & 2 & & & \\
\hline & Low land & 0 & 0 & $\sqrt{ }$ & 3 & & & \\
\hline \multirow[t]{3}{*}{ Distance from coast (in kilometer) } & Average distance & 64.9 & 65.49 & 60.86 & 1 & 2 & 1 & 3 \\
\hline & Far distance & 66.92 & 69.75 & 64.60 & 2 & & & \\
\hline & Close distance & 62.88 & 61.15 & 57.12 & 3 & & & \\
\hline \multirow[t]{3}{*}{ Distance from river (in kilometer) } & Average distance & 1 & 1.75 & 4.5 & 3 & 2 & 2 & 1 \\
\hline & Nearest distance & 0 & 0 & 3 & 2 & & & \\
\hline & Farthest distance & 2 & 3.5 & 6 & 1 & & & \\
\hline \multirow[t]{3}{*}{ Distance from embankment (in kilometer) } & Average distance & 1 & 1.75 & 4.5 & 3 & 3 & 3 & 2 \\
\hline & Nearest distance & 0 & 0 & 3 & 2 & & & \\
\hline & Farthest distance & 2 & 3.5 & 6 & 1 & & & \\
\hline \multirow[t]{4}{*}{ Distance from forest (in kilometer) } & Average distance & 2.19 & 4.69 & 2.41 & 1 & 2 & 1 & \\
\hline & Nearest distance & .95 & 2.64 & 1.65 & 2 & & & \\
\hline & Farthest distance & 3.43 & 6.74 & 3.17 & 3 & & & 2 \\
\hline & & & & & Total & 11 & 9 & 12 \\
\hline
\end{tabular}

Source Field Survey 2017

operation. Only mode of transportation in the study area is unpaved narrow road and only means of transportation is motorbike which is basically used for transportation of people, not goods. During cyclonic event people have to move on foot. Moreover, average distance of cyclone shelter from the houses is $1.5-2 \mathrm{~km}$. So, it is quite impossible to take any assets to cyclone shelter during the event, and this also enhances vulnerability.

On the basis of the total points provided in Table 1, it can be seen that the highest point is 12 gained by Patakhali village which indicates the most vulnerable village to cyclonic events in terms of influencing factors. On the other hand, gained a point of Sora is 11 and Chakbara is 9, which means that Chakbara is less vulnerable than Sora village.

\section{Sensitivity analysis}

Sensitivity analysis for economic change (Table 2) indicates that in terms of changing population structure, especially dependent-independent population ratio, sensitivity and occupational change are moderate; income change, expenditure capacity change, saving change, drinking water change, land use change, change in agricultural land use, and change in land ownership is severe; while housing structure change is positive due to external aid.

\section{Vulnerability analysis}

Vulnerability due to the cyclone Aila induced economic change is related to economic indicators, including change in number of earning population, occupation, income, expenditure capacity, saving, housing structure, access to pure drinking water, general and agricultural land use, household resources etc. The findings are as followings:

Occupational vulnerability The tropical cyclone Aila has brought change in economic activities. Mallick et al. (2011) stated that the physical infrastructure and livelihood condition of the Aila affected area are awful, therefore, the afeected people have started to sell their own resources, shift from previous occupation, even in extreme cases, migrate to the cities for alternative income sources. Fishing in fresh water and river, agricultural activities and gathering forest resources are the most common economic activities in the study area. In Sora $8.2 \%$ people have switched occupation from fishing and $5.8 \%$ from farming; in Chakbara $19.97 \%$ from fishing and 3.9\% from farming; and in Patakhali 6.3\% from fishing and $3.1 \%$ from farming to different less productive sector of earnings-basically to day labour. Hence, people were forced to work as day labours outside within their territory, such as upazila sadar (sub-district) or district sadar even in the capital city. From field survey it is found that a number of people of all villages work in brick fields in Satkhira/Khulna or capital city Dhaka for 7-9 months every year. Due to change in land use pattern, working opportunities in agriculture and fishing sectors have been reduced, which creates a serious unemployment problem in this area. 


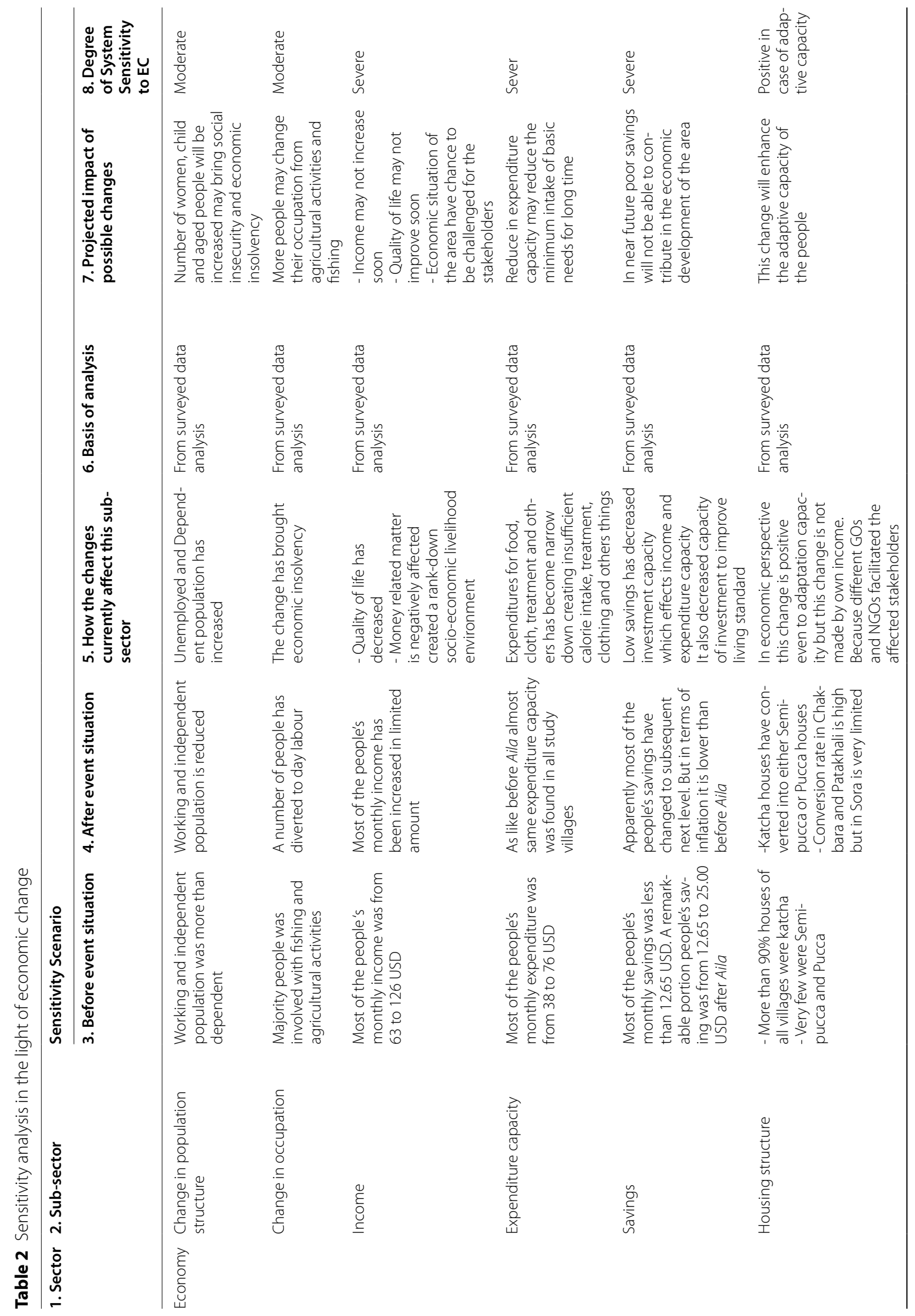




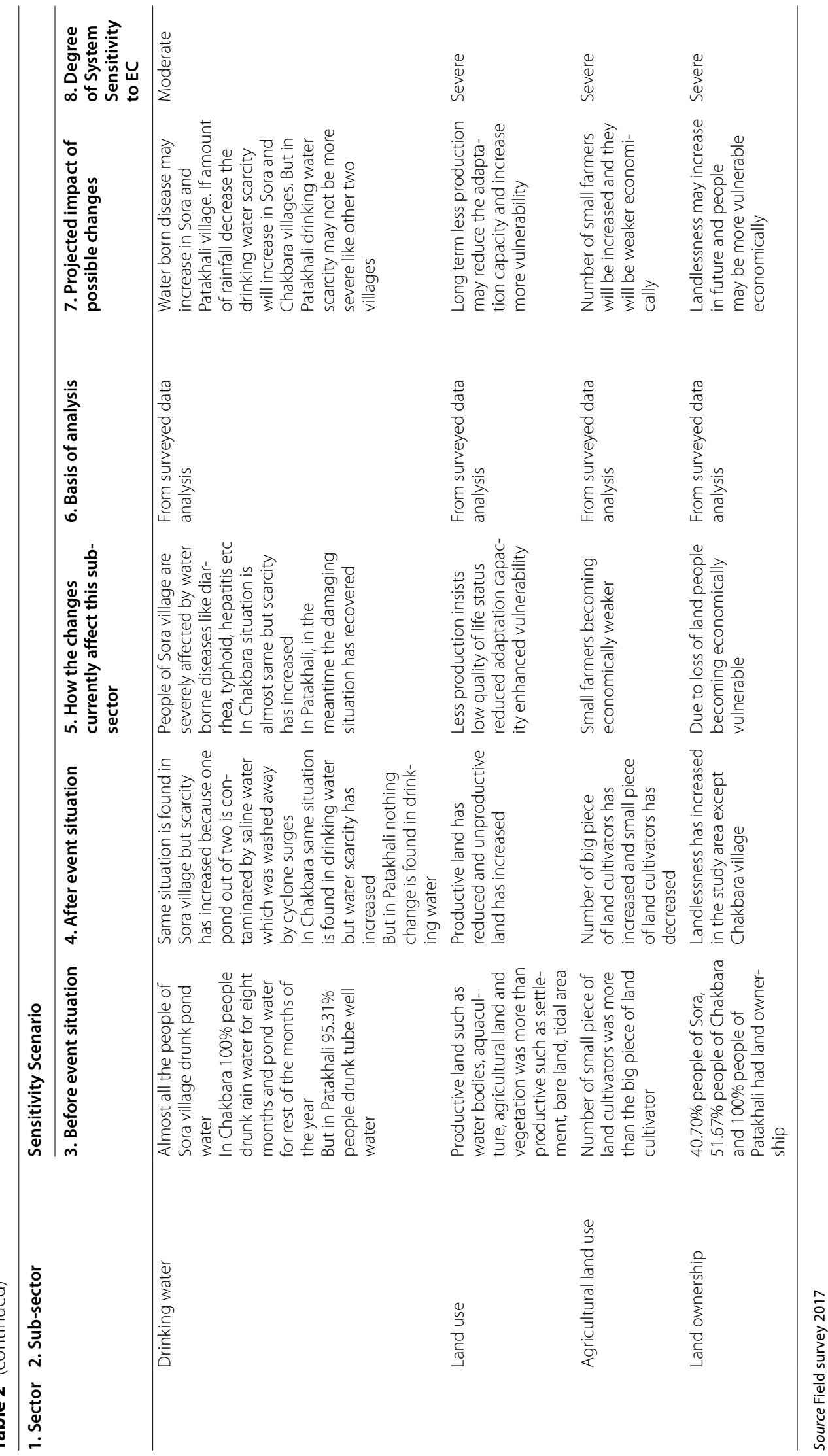


Income vulnerability The national per capita income of Bangladesh was 618.1 US dollar in 2008 and 1314 USD in 2015. During this period the increase rate is $112.62 \%$ (BBS 2015). Before Aila, the per capita income in the study area ranged between 63 and 126 USD. Keeping up with the swelling of national income, their income should have ranged between 190 and 253 USD after Aila. Still now, the income of the majority of the people is from 63 to 126 USD per month in all villages except Chakbara, which is comparatively in better condition. If the inflation rate is considered, the range should be from 190 to 253 USD per month. So, it can be said that people's income level has not risen, indicating that people's income opportunity is not in accordance with the economic progress of the country due to Aila.

Expenditure vulnerability Expenditures depend on income level. As the income level remains unchanged, it compels people to shrink their expenses for their basic needs. The expenditure pattern has changed both in sectoral and total expenditure. The expenses of the villagers have increased, but their management of expenses does not correspond to the necessity of the villagers. Before Aila, most of the people's expenditure was between 76 and 114 USD per month, which was little bit increased after Aila except in Patakhali village. Before Aila, expenditure group population of 76-114 USD was 60.47, 53.33 and 65.63 percent in Sora, Chakbara and Patakhali respectively; which has become 61.63, 66.67 and 59.38 percent respectively after Aila. Though a slight increasing trend of expenditure group population in Sora and Chakbara is observed, it is not up to the mark considering the inflation rate. Due to low expenditure, food calorie intake has also been reduced. Expenditure for treatment has reduced as an aftermath of Aila though they are suffering from different diseases. Likewise, expenditure for housing is very low and people make their house not too strongly which are unable to survive next cyclonic effects. So, it is needless to say that this susceptible situation makes the area more vulnerable for any upcoming cyclonic events.

Saving vulnerability Like income and expenditure, the savings of the people are very limited amounting less than 12.5 USD per month, which is too low for any investment. Besides, this low saving is not sufficient to plan for investing into any income generating activities. Moreover, during extreme event they are unable to pay for basic needs like food, water, treatment, reconstruction of houses etc. which increases the vulnerability of the stakeholders of the area.

Vulnerability to housing structure Survey result indicates that almost $80 \%$ houses in the affected area were fully damaged, 8-20\% houses were mostly damaged and very few houses were partially damaged by Aila. The housing structure change analysis shows a positive change basically in pucca and semi-pucca house after Aila. In Sora, pucca house reaches from 2.5 percent to 4.65 percent, in Chakbara from 2.9 to 13.33 percent and in Patakhali from 1.95 to 21.87 percent after Aila. Though, the change is positive in structure, but the buildings are not too strong to prevent cyclonic effects. Moreover, after Aila, for a long time a major portion of the people were unable to rebuild their houses. During the field survey, from different official sources it has been found that various GOs and NGOs help the affected family to rebuild damaged houses through house building project.

Drinking water vulnerability Drinking water vulnerability depends on availability and drinking suitability of groundwater. The groundwater source of village Sora and Chakbara is contaminated by salinity whereas Patakhali is free from excess contamination of any unwanted elements. All the people of Patakhali drink tube-well water, which is hygienic; but people of Sora and Chakbara drink harvested rain water or pond's water. While the rain water is hygienic, pond water is not. The harvested rain water is sufficient to supply only for three to four months. So, people have to drink unhygienic pond water for rest of the year on a regular basis. Few people are economically solvent to pay for bottled water or harvested rain water, but others have to drink untreated and unhealthy pond water. So, people who are economically weak are more vulnerable to scarcity of safe drinking water.

Land use vulnerability Land is a prime source of earning as men perform economic activities on land; while economic status depends on having landed properties and their productivity. Sensitivity analysis represents that there are two types of land in the study area, productive land-water bodies, aquaculture, agricultural land and vegetation, and non-productive land-settlement, bare land, and tidal area. After the Aila the productive lands have turned into less productive land. For example, in Sora village productive agricultural land has been converted into non-productive bare land and tidal land, and to less productive aquaculture. In Chakbara productive agricultural land has been transformed into less productive aquaculture and non-productive bare land. Likewise, in Patakhali village, productive aquaculture has been converted into permanent water bodies. It can be mentioned here that apparently aquaculture, basically shrimp cultivation, is more profitable than agricultural activities, but due to siltation its productivity has also decreased dramatically in the area (Fig. 6). Moreover, for aquaculture only two labourers are suf- 


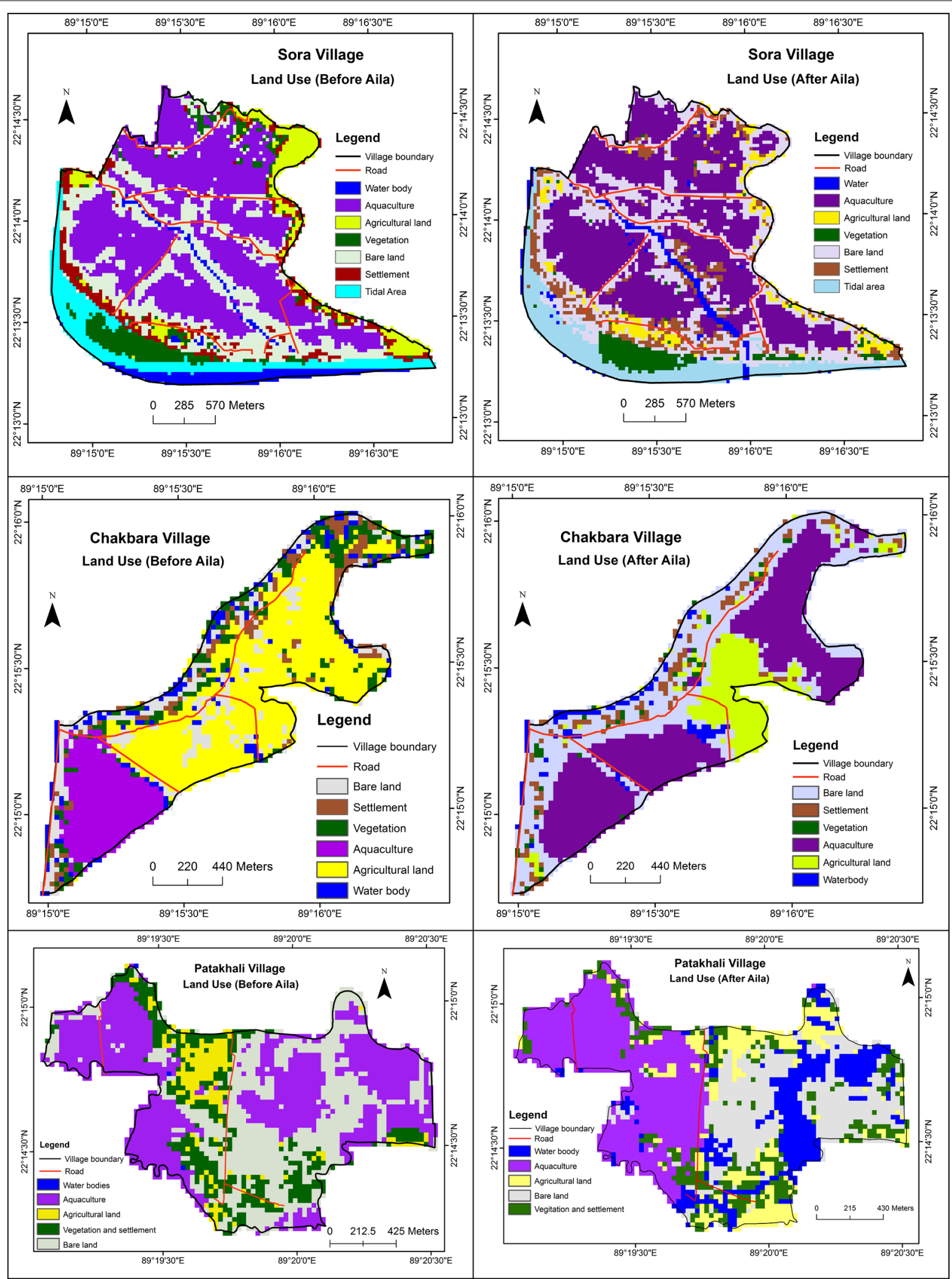

Fig. 6 Land Use change in the study area 
ficient, whereas for agriculture more than ten labourers are needed on the same amount of land. As a result, a huge number of people of the area have become unemployed that pushes the area to economical vulnerability.

Agricultural land use vulnerability Aquacultural practice has increased in all the villages. But small size aquaculture "Gher" (shallow water marshy land which is used for shrimp/crab cultivation.) has been converted into bigger ones while small farmers have become land less. Similarly, aquacultural practices have also reduced the cultivable land in the study area. The vegetables cultivation area also has been reduced except in Chakbara village, where little expansion is observed. Hence, no crop is found except shrimp/crab cultivation. Shrimp/ crab is cultivated for commercial purpose, because the agricultural practice in this area is focused only to provide for subsistence. So, this change is vulnerable to the livelihood of the people of this area. It is predicted that this area will be more vulnerable if any extreme cyclonic event will hit this area recurrently.

Land ownership vulnerability Land ownership is considered a vital element of rural economy especially for agricultural activities. A small decreasing change in land ownership is found in the study area except in Chakbara village. Though the change in overall land ownership is very limited but in case of agricultural land ownership, it is remarkable. The small amount of land is sufficient to provide foods through agricultural practices, but due to conversion into aquaculture this small piece of land is unable to supply necessary food demand, and the owner is forced to sell the land. Again, the big farmers by applying their social power make people sell the land cheaply. As a result, they become vulnerable in two ways: firstly, they lose their source of income; and secondly, they are to move out to other nearby city or capital city. The severity of the change may increase in the near future because recovering from this situation needs integrated programme between government and stakeholders which is still absent.

Household resources vulnerability The household's equipment depends on the economic status of the stakeholders. During the survey, houses are found to be very poorly furnished exposing the residents of the area to be economically poor. Most of the households are facilitated with cell phone and solar power. The number of solar power connectivity has increased in all the villages. Though Patakhali is facilitated with electricity connection, the Aila has destroyed the system and it is yet to be reset. In case of other resources, most of the people have up to 177 USD equivalent resources. That is very much limited to get preparation to cope with any upcoming event.

Infrastructure vulnerability As a backward area, few paved roads, school buildings and cyclone shelters are the main infrastructures found in the study area. This road is only suitable for transport like two wheelers. There are cyclone shelters in Sora and Chakbara villages, but not in Patakhali village. The nearest cyclone shelter is almost $3 \mathrm{~km}$ away from Patakhali village. Moreover, accommodation capacity of the cyclone shelters is one-fourth of the total population. Likewise, road communication from houses to cyclone shelters is not convenient. There is no transport in the area by which people and resources can be brought to cyclone shelters during emergency. On the other hand, to protect from tidal and cyclonic surges the areas are bounded by embankment alongside the riverbank. Due to lack of proper maintenance this embankment is too weak to survive when surges hit. During the Aila the embankment was overtopped by strong surges, the area inundated by 10 feet height water and all things went under saline water. Four points of the embankment were damaged and the area was being washed away twice daily by tidal surges. After three years, the damages are recovered by the construction of closure. During this time, the area was contaminated by over salinity which has made the area unsuitable for further agricultural activities. This area has undergone similar experiences again with the cyclone Amphan in 2020 and become more susceptible for any further cyclonic event. There is a relationship between climate change, sensitivity of the factors, physical susceptibility, economic susceptibility and vulnerability is shown in Fig. 7.

\section{Adaptation strategy}

Adaptation is an integrated concept that includes environmental, economic, political, social and psychological factors. The IPCC (2007) defines climate change adaptation as 'adjustments in natural or human systems in response to actual or expected climatic stimuli or their effects, which moderates harm or exploits beneficial opportunities'. Adaptation is nothing but adjustment or actions undertaken which creates opportunities to minimize adverse effects of any physical and cultural environmental change made due to climate change. This is dependent on available economic resources; technology, information and skills; infrastructure and institutions; and indigenous knowledge and equity. It also depends on what natural calamities they are vulnerable to (droughts, storms, cyclones etc.), who is vulnerable, how future vulnerability will be shaped, and at what scales. However, keeping these in mind vulnerability discussion as adaptation strategy taken by the stakeholders are as follows: 


\section{Adaptation to occupational vulnerability}

Mallick et al. (2011) shows that the existence of social networks or an institutional set-up in the area for a more collective ex-ante or ex-post strategy to cyclone and tidal surges is very thin. Sometimes, the affected people move to nearby cities as a rickshaw puller or industry labourer and they bring others. Such ruralurban migration in Bangladesh is a household based strategy for maximizing income or well-being and is partially dependent on the support of the other family members, and/or district-based acquaintances, friends and neighbours. The respondents perceived migration as a way of maximizing their family's income and minimizing its risk. In terms of occupation, people of this area are susceptible. From the vulnerability analysis, it is found that people are bound to engage themselves in low paid occupations. To adopt with the changing situation, people work as day labourers either in their nearby locality or any other city across the country. The field survey result indicates that those are working as day labourers are mostly brickfield's worker. Moreover, many people take up motorcycle driving as their main or part-time occupation, because roads are unpaved and in many cases on the embankment of the rivers. Roads are narrow and not suitable for any vehicle, except two wheelers. So, to transport people and goods an important means of transportation is the motorcycle. That is why people accept motorcycle driving as a profession to adopt with the adverse situation. Moreover, people, basically women, collect shrimp larvae from river to earn money. They also capture numerous other fries using a very small net. Besides, they also work in the Gher to remove weeds that grow and float on the water, pollute the water and hamper the fish production. They get 1.26 USD per day to clean the Gher (Sultana and Mallick 2015). Alternative livelihood options are very limited in the area. Recently, crab fattening is found as highly profitable and growing sector, though it is limited in scale and can be emerged as a supplementary occupation of the people in the future.

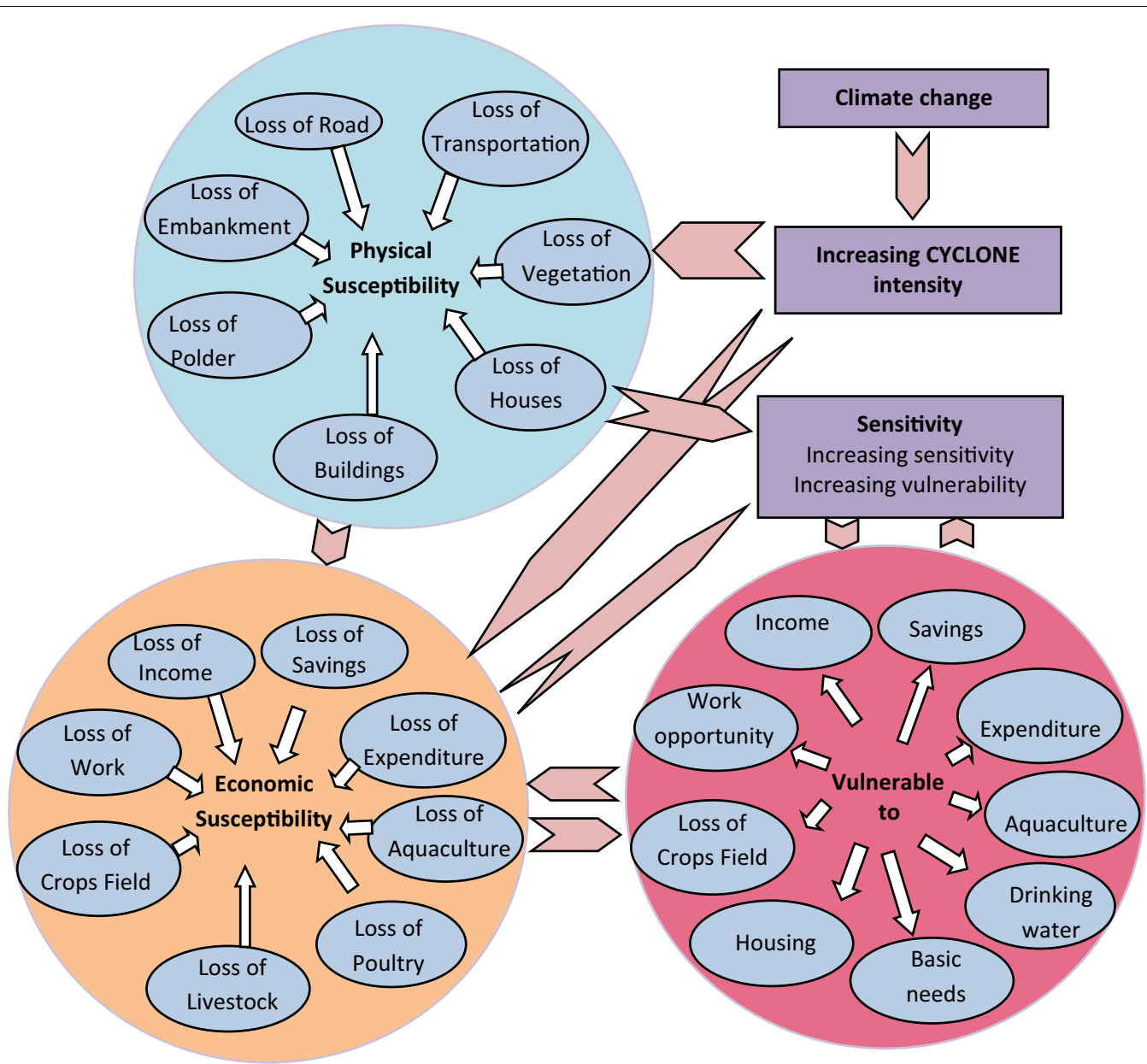

Fig. 7 Linkage among cyclone, physical and economic susceptibility, vulnerability and sensitivity 


\section{Adaptation to income, expenditure and saving vulnerability}

Income, expenditure and saving are highly correlated with occupation. Due to diversion from more productive occupations to less productive ones, income, expenditure and savings of the dwellers are highly susceptible. If the inflation rate is considered, the income of the dwellers actually has been reduced, impacting their expenditure and saving. To adjust with reduced income, people have cut down their expenditure on food, cloths, treatments and other daily expenditures. People are trying to increase income through engaging in different main and supplementary works such as shrimp larvae collection from the river, cattle rearing, crab fattening, and homestead vegetables cultivation. However, people save money to adopt with the future hazard, and they do not spend this money even though it is small in amount.

\section{Adaptation to housing structure change vulnerability}

As an aftermath of the cyclone Aila, people were forced to take shelter on the roads or the embankments, building temporary huts. Only once the embankments were repaired, a few months later after Aila, after which the inhabitants began to return to their old places. During construction or renovation of houses, some households shifted their homes to a higher place or changed their materials so that the houses can cope with a future cyclone (Sultana and Mallick 2015). After the Aila 18.60\% of Sora, $60.00 \%$ of Chakbara and $78.13 \%$ of Patakhali people have brought changes in their housing structure. Hence, $8.14 \%$ people of Sora, $6.67 \%$ people of Chakbara and $100 \%$ people of Patakhali village have changed their houses as pre-disaster adaptation. The change has been made through plinth raising, change in the plinth and building materials, for example, the plinth of houses in all three villages mostly was made with mud and very few were made of wood or concrete before the Aila. But after the Aila those who are economically solvent, have made the plinth of the houses with wood or concrete. Moreover, 100 percent people have raised plinth of the house considering the previous experience of the height of the land and the probable height of cyclonic surges. Plinth of most of the houses of Sora and Chakbara villages has risen by $2-3$ feet and Patakhali by $1-3$ feet (Table 3 ). Likewise, materials of housing have been changed after the Aila. The number of houses with mud constructed walls has reduced, whereas the number of wooden, tin sheet and concrete made houses has increased. Changing the rate of wooden wall houses is higher in Sora; tin sheet wall houses is higher in Chakbara and concrete wall is higher in Patakhali. Because, wooden or tin sheet or concrete walls are more water resistant than mud walls.

\section{Adaptation to general and agricultural land use vulnerability}

The study reveals that major change in land use is found from agriculture to aquaculture and also to bare land due to the Aila. Embankments around the villages weredamaged by the storm surges of the cyclone Aila and total area went under water. The area was flooded with saline water twice daily until closures were built on broken embankments after three years of the event. As a result, a huge amount of land has been converted into aquaculture land. Moreover, due to increased salinity and high tidal inundation agricultural crop cultivation has reduced in the area. Shrimp cultivation that started in the mideighties are still prevalent, although the production has reduced tremendously due to cultivation for a long time, years after years on the same land. Paddy cultivation is also not possible due to severe saline commination in the soil (Alauddin and Khan 2013). However, people raise the height and width of the bank of Ghers to protect fishes from the risks of high tidal inundation and tidal surges considering water level. People also put pata (made by bamboo stick and rope which put on the boundary of Ghers to protect fishes. It allows water to go in and outside during high and low tide) and net to protect fishes from the same situation. On the other hand, return from aquaculture is lower than that from the crop cultivation. So, people are trying to cultivate saline tolerate crops, basically different types of rice, but still now in small scale. On the other hand, bare land is being tried to bring under social forestry and homestead land under vegetable cultivation.

\section{Adaptation to drinking water vulnerability}

The study villages, except Patakhali, have drinking water scarcity. Dakkhin Bedkashi union of Khulna district and Gabura union of Satkhira district are separated by the Kobodak River. But surprisingly the groundwater of Gabura Union is contaminated by salinity whereas Dakkhin Bedkashi is free from saline contamination. So, people of Sora and Chakbara have been suffering from scarcity of pure drinking water, and are mostly dependent on pond water, whereas Chakbara is dependent on rain, pond and treated water. During rainy season, people harvest rain water and store in earthen vessels. They use this water for four to six months on the basis of storing capacity and rest of the year on pond water. During use of pond water, few people use water purifying medicine and few people do not take any measure of water purification.

\section{Adaptation to households resources vulnerability}

For quick recovery and adjustment with the damages which took place just after the Aila, people sold off their household resources. According to Sultana and Mallick 
Table 3 Change in housing structures and materials to adapt with the situation (in percentage)

\begin{tabular}{|c|c|c|c|c|c|c|}
\hline & \multicolumn{2}{|l|}{ Sora } & \multicolumn{2}{|l|}{ Chakbara } & \multicolumn{2}{|l|}{ Patakhali } \\
\hline & Before Aila & After Aila & Before Aila & After Aila & Before Aila & After Aila \\
\hline \multicolumn{7}{|l|}{ Plinth rising } \\
\hline Yes & 8.14 & 18.60 & 6.67 & 60.00 & 100.00 & 78.13 \\
\hline No & 91.86 & 81.40 & 93.33 & 40.00 & 0.00 & 21.88 \\
\hline Total & 100.00 & 100.00 & 100.00 & 100.00 & 100.00 & 100.00 \\
\hline \multicolumn{7}{|c|}{ Plinth structure change } \\
\hline Mud & 93.02 & 88.37 & 88.33 & 58.33 & 100.00 & 75.00 \\
\hline Wooden & 4.65 & 8.14 & 3.33 & 18.33 & 0.00 & 6.25 \\
\hline Concrete & 0.00 & 1.16 & 6.67 & 21.67 & 0.00 & 18.75 \\
\hline Others & 2.33 & 2.33 & 1.67 & 1.67 & 0.00 & 0.00 \\
\hline Total & 100.00 & 100.00 & 100.00 & 100.00 & 100.00 & 100.00 \\
\hline \multicolumn{7}{|c|}{ Plinth height in feet } \\
\hline$<1$ feet & 40.10 & 1.16 & 23.48 & 6.67 & 32.78 & 12.50 \\
\hline $1-2$ feet & 39.90 & 13.95 & 17.34 & 15.00 & 37.74 & 40.63 \\
\hline 2-3 feet & 10.75 & 61.63 & 40.88 & 50.00 & 25.25 & 39.06 \\
\hline 3-4 feet & 6.63 & 19.77 & 15.74 & 25.00 & 4.23 & 7.81 \\
\hline \multirow[t]{2}{*}{$4<$ feet } & 2.62 & 3.49 & 2.56 & 3.33 & 0.00 & 0.00 \\
\hline & 100.00 & 100.00 & 100.00 & 100.00 & 100.00 & 100.00 \\
\hline \multicolumn{7}{|c|}{ Structural change of houses } \\
\hline Yes & 4.65 & 6.98 & 5.00 & 46.67 & 0.00 & 64.06 \\
\hline No & 95.35 & 93.02 & 95.00 & 53.33 & 100.00 & 35.94 \\
\hline Total & 100.00 & 100.00 & 100.00 & 100.00 & 100.00 & 100.00 \\
\hline \multicolumn{7}{|c|}{ Housing structure } \\
\hline Mud wall & 93.02 & 83.72 & 63.33 & 30.00 & 96.88 & 64.06 \\
\hline Wooden wall & 3.49 & 10.47 & 25.00 & 38.33 & 1.56 & 10.94 \\
\hline Tin sheet & 1.16 & 1.16 & 3.33 & 10.00 & 1.56 & 6.25 \\
\hline Concrete wall & 0.00 & 2.33 & 6.67 & 20.00 & 0.00 & 18.75 \\
\hline Others & 2.33 & 2.33 & 1.67 & 1.67 & 0.00 & 0.00 \\
\hline Total & 100.00 & 100.00 & 100.00 & 100.00 & 100.00 & 100.00 \\
\hline
\end{tabular}

Source Field survey 2017

(2015) as a coping strategy with the adverse situation induced by cyclone, $17.4 \%$ of the respondents sold their resources, of which $66.3 \%$ sold cattle and other livestock due to monetary urgencies and the burden of a shortage of fodders and adequate shelters. 59.6\% sold their broken or even non-broken trees and plants (timber or wood plants) and only 5.9\% sold ornaments or other household assets like TV, mobile phone, radio etc. and few of them their land. In the study, it is found that houses in the area are poorly equipped, because the income is too marginal to provide food and others basic needs than buy household's equipment. However, it is surprising that stakeholders do not have planned well to save and manage the remaining household equipment, pre-hazard, post-hazard or during hazard. But they apply few indigenous techniques to protect the household resources. As pre-disaster preparedness people build macha (made by bamboo and rope about 5-8 feet height from the ground, which stands on four to six bamboo pillars. Mostly situated inside house for taking shelter and put goods during cyclone/cyclonic surges/flood) in the room and put resources on it during events. Besides, food and other necessary goods put underground packaging in waterproof polythene bag when cyclone hit the area.

\section{Role of GOs and NGOs to adapt the situation}

In the study it is found that different GOs and NGOs have helped people to develop livelihoods through improvement of plans and activities with the local community to reduce their disaster risks and to adapt to climate change. The Government of Bangladesh has a number of well-established social safety net mechanisms 
prepared in response to the event of a disaster, namely, vulnerable group development (VGD), vulnerable group feeding (VGF), Cash/Food-for-Work, test relief (TR) and gratuitous relief (GR). Similarly, several NGOs like World Vision, CARITAS, Christian Commission for Development in Bangladesh (CCDB), Progoti, Islamic Relief, Gono Mukhi, Rupantor, Muslim Aids, Broti, Relief International, IPack, Uttoron etc. Bangladesh has short, mid and long term programmes to address the adverse impact of climate change. Mass awareness development training and advocacy progarmmes, tree plantation and afforestation, mainstreaming climate change issues into sectoral development policies and programmes, networks among organizations, civil society and media are short term; renewable energy development, improved water resource management, food security and crop diversification programmes are mid-term; and research, afforestation, development of suitable crop varieties, incorporation climate change issues in educational curriculum, infrastructures development and undertaking adequate projects and programmes are long-term programmes.

In order to manage disaster more comprehensively, Bangladesh has introduced the National Plan for Disaster Management 2010-2015. The aim of the plan is to take the country's disaster management from conventional methods to more comprehensive strategies in the light of paradigm shift of disaster management. The National Disaster Management Council (NDMC) and the InterMinisterial Disaster Management Coordination Committee (IMDMCC) are responsible to coordinate disaster related activities at the national level. The Disaster Management and Relief Division (DMRD) under the Ministry of Food and Disaster Management (MoFDM) of the Government of Bangladesh coordinates national disaster management activities across the agencies. The Disaster Management Bureau (DMB), a technical arm of DMRD is responsible for over viewing and coordination all activities related to disaster management from national down to grass-roots level. Under DMB district, Upazila and Union level Management Committee work together with civil society member. The Union Disaster Management Committee (UDMC) is the lowest administrative unit of disaster management. The UDMC consists of the Chairman of the Union Parishad as Chairperson and members comprising all the Government Departments' head at the Union level, members of Union Parishad, NGO leaders working with the respective union, and civil society members. It is found that GOs are more active during disaster than the pre- and post-disaster. For example, the damaged embankment was not repaired for a long time after Aila. Though it was repaired after a long time, but not as strong to protect from any upcoming event.
NGOs have played significant roles in the disaster management in Bangladesh over the last three decades. At present, a quarter of all foreign assistance to the country is channeled through the NGOs and increasing portion of these funds is used for disaster management. The $\mathrm{DMB}$, the apex government organization responsible for coordination natural disaster management across all agencies, has been assigned the role of coordination the NGOs activities. The NGOs played relatively a better role in providing food, water, clothes, medicine, etc. (Hossain 2020) and both national and international ones, have been implementing a range of relief and rehabilitation programmes after the cyclone Aila. Immediately after the cyclone, NGOs mainly involved themselves in the humanitarian relief distribution and later they have taken on numerous rehabilitation programmes. The immediate support of NGOs has been diverse in nature and has included asset (such as boats, nets, livestock and food), and cash transfers; and other non-food and emergency items (such as jerry cans, mosquito nets, pure water). These emergency interventions have initiated to address the basic survival and protection needs of the affected households. The taken relief and rehabilitation programmes helped people in sustaining livelihood after the Aila.

However, during the survey, a number of NGOs were found working till now from after the Aila. But their aim and activities are different. For example, CARITAS arranged training programme on 'How to build cyclone and cyclonic surges resistance house' through "Amrao Pari" programme. Along with the training they provided twenty thousand taka per house for plinth rising and repair wall and others structures of house in Sora and Chakbara village, though only few houses got this aid. In order to overcome the drinking water problem CARITAS also provided dram to harvesting and storing rain water. There is another programme of CARITAS to conduct training programme in order to train up farmers with salient tolerant crop cultivation. In Patakhali village, UNDP built up a number of concrete houses for the victims. These houses are strong enough to protect cyclone surges. Roof of these houses are used for rain water harvesting, which is used for drinking purpose. Center for Natural Resource Studies (CNRS) is working for recovering agricultural activities in the affected area. They arrange training programmes to train up affected people how to cultivate saline tolerant varieties crops. CCDB dug one pond for each of the villages Sora and Chakbara in order to supply drinking water. They have also established drinking water purifying plant for these two villages. 


\section{Conclusion and recommendation}

Bangladesh is not liable for climate change, but she is the worst sufferer. From the discussion of the study, it is found that people have become economically vulnerable due to the cyclone Aila. Based on the research results and discussion, it can be concluded that before the Aila economic systems of the area was suitable for crops based agricultural activities and people were solvent enough to meet up their basic needs. Due to Aila it was inundated by the saline water and shrimp cultivation has replaced the major portion of crop cultivation. As a result, people have lost their jobs, income opportunity, expenditure capacity, which have affected all the livelihoods relevant issues like shelter, foods, education, clothing, treatment etc. Even after a long time of the Aila the area is still unable to recover from the situation. A number of programmes and activities have been taken by different GOs and NGOs with the help of national and international organizations. However, still now people are far from the condition they were in before Aila. Because, the activities taken by different organizations are different in nature as per their objectives. It is observed that till today there is no specific agency responsible for integration of coastal area planning in Bangladesh; therefore, all different agencies, which have responsibilities for different sectors have to be included to work together. It is expected that proper planning and good governance can also mitigate/reduce any sort of hazard, out migration and can increase the economic situation as well as livelihood through different income generating schemes in collaboration of government, nongovernment and international agencies. Moreover, for quick recovery, better management and to develop a sustainable adaptation strategy the study has suggested the following recommendation.

- To recover economic vulnerability more work opportunities for the people should be created. For this, dependency on shrimp cultivation should be reduced by creating other crops cultivation opportunities, because shrimp cultivation needs fewer labourers than is needed by cultivating crops. It is quite impossible to reduce salinity of the soil immediately. However, it is possible to cultivate saline tolerate crops. Different organizations (donor agencies) have supplied saline tolerate crops to the stakeholders which is very insufficient to fulfill the requirements of the area. So, the agriculture department of Bangladesh government has to ensure the availability of saline tolerate seeds of different crops for the farmers. Government should supply the seeds free or at a subsidized rate. Moreover, different programmes such as publicity, training, motivational programme etc. can be arranged for inspiring and promoting farming activities.

- Due to deposition of sediment with cyclonic surges of Aila per unit shrimp production of the area has reduced. To enhance productivity government has to monitor and give necessary advice to the farmers through Block Supervisors (BS).

- Other agricultural activities like poultry, dairy and livestock can be introduced in the area. Government should take necessary steps to train up farmers and provide logistics like capital through soft loan, chicken, vaccine etc.

- During the survey, it was found that the embankments around the area to protect from high tide and cyclonic surges were old and almost damaged in condition. These embankments are too weak to protect the villages from high tide and cyclonic surges. Only planned construction of embankment with appropriate drainage system, height and width considering cyclone water level can protect the aquaculture, livestock, agricultural crops and infrastructures as the effective adaptive structural measures in this area. So, it is utmost necessity to repair and maintain embankments in a regular basis.

- Roads are unpaved and their density is very low. Access to cyclone center during events is quite difficult and time consuming. Roads are needed to be widened, repaired and paved urgently. Besides, to raise accessibility more roads need to be constructed.

- Compared to the population, number of cyclone shelters is insufficient. It is already mentioned that there is a cyclone shelter in each Sora and Chakbara village, but there is no cyclone shelter in Patakhali village. So, more cyclone shelters need to be established.

- Plinth raising is one of the common and popular adaptation strategy to protect houses from the risks of climate disaster, particularly, cyclone and flood in the coastal and flood prone areas. In the study area plinth raising is often adopted by mostly individual initiative and NGOs support without considering the water level of flood and storm surge trend analysis of past events and future prediction, which need to be addressed for the long-term sustenance of the structures.

- Tree plantation around homestead, alongside the road, bare land and alongside the embankment by the individual initiative or under social forestry programme of different GOs and NGOs is another adaptation practice in the study area. But this is very 
limited as compared to the need. So, it is necessary to inspire people to intensive homestead tree plantation through GOs and NGOs activities. Moreover, under social forestry programmes, initiatives should be taken to afforestation of damaged forestry in large scale.

- To cope, the Bangladesh government has required more skilled manpower, more effective planning, an increase in economic strength, more in-depth studies, an increase in resources and an improved and adequate infrastructure. Gathering evidence of climate change and its impact at the local level, placing emphasis on local ecological knowledge and traditional innovation, and analysing community-level preparedness are essential components of the planning necessary to combat the impacts of climate change.

- Even more importantly is that local people need to participate in policy making and programmes dealing with GOs and NGOs to face climate change impacts, and mitigation and adaptation. Community-based adaptation should, therefore, be a central tenet of action on climate change in Bangladesh.

\begin{abstract}
Acknowledgements
Authors are thankful to the participants those have contributed by providing information during questionnaire survey and focus group discussion. We would also like to acknowledge Google Earth Explorer from where used images were extracted without any cost.
\end{abstract}

\section{Authors' contributions \\ The whole research work was a team work. As a lead author, the whole work was planned and done especially identification of the problem, data collec- tion, tabulation, analysis, explanation and write up by me with the help of AHMHI. Similarly, ZA was taken part in the research by acquiring and analysing imageries to land use change detection. Accordingly, Md.AH and Md.RA contributed to the research by collecting data through questionnaire survey from study area with other authors. All authors read and approved the final manuscript.}

\section{Funding}

Not applicable.

\section{Availability of data and materials}

Most of the used data and materials in the study are produced by the authors through field survey. Other supplementary data are cited properly.

\section{Declarations}

\section{Competing interests}

The authors declare that they have no competing interest.

\section{Author details}

'Department of Geography and Environmental Studies, University of Rajshahi, Rajshahi, Bangladesh. ${ }^{2}$ Bangladesh Oceanographic Research Institute, Pechardwip, Bangladesh. ${ }^{3}$ Institute of Environmental Studies, University of Rajshahi, Rajshahi, Bangladesh.

Received: 10 July 2020 Accepted: 17 February 2022

Published online: 25 February 2022

\section{References}

Adger NW (2006) Vulnerability. Glob Environ Change 16:268-281

Alauddin SM, Khan FR (2013) Vulnerability to climate change and adaptation practices in Bangladesh. J SUB 4(2):25-42

Ali A (1999) Climate change impacts and adaptation assessment in Bangladesh. Clim Res 12:109

BBS (2015) Bangladesh Bureau of Statistics, Population Census, Ministry of Planning. Government of the People's Republic of Bangladesh, Dhaka

Birkmann J (2006a) Measuring vulnerability to promote disaster-resilient societies: conceptual frameworks and definitions. In: Birkmann J (ed) Measuring vulnerability to natural hazards: towards disaster resilient societies. United Nations University Press, Tokyo, pp 9-54

Birkmann J (2006b) Conclusion and recommendation. In: Birkmann J (ed) Measuring vulnerability to natural hazards: towards disaster resilient societies. United Nations University Press, Tokyo, pp 432-447

Blaikie P, Cannon T, Davis I, Wisner B (1996) Vulnerabilidad, el entorno social de los desastres, La RED-ITDG, Bogota, D.C.

Brien O, Leichenko KR, Kelkar U, Venema H, Aandahl G, Tompkins H, Javed A, Bhadwal S, Barg S, Nygaard L, West J (2004) Mapping vulnerability to multiple stressors: climate change and globalization in India. Glob Environ Chang 14:303-313

Brooks N, Adger NW, Kelly MP (2005) The determinants of vulnerability and adaptive capacity at the national level and implications for adaptation. Glob Environ Change Part A 15:151-163

Cannon T (2006) Vulnerability analysis, livelihoods and disasters. In: Ammann WJ, Dannenmann S, Vulliet $L$ (eds) Risk 21: coping with risks due to natural hazards in the 21st century. Taylor and Francis Group plc, London, pp 41-49

Cardona OD (1990) Terminología de Uso Común en Manejo de Riesgos, AGID Reporte No. 13, EAFIT. In: Fernández MA (ed.) Medellín, actualizado y reimpreso en Ciudades en Riesgo, La RED, USAID

Carreño ML, Cardona OD, Barbat AH (2007) Urban seismic risk evaluation: a holistic approach. Nat Hazards 40(1):137-172

CDP (2006) Situation analysis on Child rights violation. In: Shrimp sector in the southwest coastal region of Bangladesh.

Center for Science in the Earth System (The Climate Impacts Group) (2007) Preparing for climate change-A Guidebook for Local, Regional, and State Governments. Joint Institute for the Study of the Atmosphere and Ocean, University of Washington, King County, Washington

Damen M, Van CJ, Westen DM, Westen, VCJ (2015) Modelling Cyclone Hazard in Bangladesh in http://www.adpc.net/casita/Case_studies/Coast al\%20hazard\%20assessment/Modelling\%20cyclone\%20hazard\%20in\% 20Bangladesh/Modelling_Cyclone_Hazard_Bangladesh.pdf

DDM (Department of Disaster Management) (2009) Summary of Cyclonic Storm AlLA. Government of Bangladesh, Dhaka. http://www.ddm.gov. bd

Durand P, Anselme B, Defossez S, Elineau S, Gherardi M, Goeldner-Gianella L, Longepee E, Nicolae-Lerma A (2018) Coastal flood risk: improving operational response, a case study on the municipality of Leucate, Languedoc, France. Geoenviron Disasters. https://doi.org/10.1186/ s40677-018-0109-1

Gbetibouo GA, Ringler C, Hassan R (2010) Vulnerability of the South African farming sector to climate change and variability: an indicator approach. Wiley Online Library, pp 175-187

Geo Consult (2004) Digital Mapping and Surveying Services. Dhaka

Hay JE, Mimora N (2005) Sea-level rise: implications for water resources management. Mitig Adapt Strat Glob Change 10:727

Hossain B (2020) Role of organizations in preparedness and emergency response to flood disaster in Bangladesh. Geoenviron Disaster. https:// doi.org/10.1186/s40677-020-00167-7

IPCC (2007) Climate change 2007: impacts, adaptation and vulnerability, contribution of working group II to the fourth assessment report of the intergovernmental panel on climate change. In: Parry ML, Canziani OF, Palutikof JP, Linden PJVD, Hanson CE (eds.) Cambridge University Press, Cambridge, pp 7-22

Kelly M, Adger N (2000) Theory and practice in assessing vulnerability to climate change and facilitating adaptation. Clim Change 47:325-352

Liverman DM (1990) Vulnerability to global environmental change. In: Kasperson RE, Dow K, Golding D, Kasperson JX (eds) Understanding global environmental change: the contributions of risk analysis and management. Clark University, Worcester, pp 27-44 
Mallick B, Rahaman KR, Vogt J (2011) Coastal livelihood and physical infrastructure in Bangladesh after cyclone Aila. Mitig Adapt Strat Glob Change 16(6):629-648

Maskrey A (1984) Community based hazard mitigation. In: Disasters mitigation program implementation. Virginia Polytechnic Institute

McCarthy JJ, Canziani OF, Leary NA, Dokken DJ, White KS (2001) Climate change 2001: impacts, adaptation and vulnerability. Cambridge University Press, Cambridge

OCHA (2009) In: USAID, Bureau for Democracy, Conflict, and Humanitarian Assistance (DCHA) office of U.S. Foreign Disaster Assistance (OFDA)

Parajuli RR (2020) Citizen disaster science education for effective disaster risk reduction in developing countries. Geoenviron Disasters. https://doi.org/ 10.1186/s40677-020-00150-2

Rayner S, Elizabeth LM (2000) Climate change, poverty, and intergenerational equity: the national level. In: Munasinghe M, Swart R (eds) Climate change and its linkages with development, equity, and sustainability, IPCC and WMO, Geneva, pp 215-242

Sultana Z, Mallick B (2015) Adaptation strategies after cyclone in southwest coastal Bangladesh-Pro Poor Policy Choices. Am J Rural Dev 3(2):24-33

Thywissen K (2006) Core terminology of disaster reduction: a comparative glossary. In: Birkmann J (ed) Measuring vulnerability to natural hazards: towards disaster resilient societies. United Nations University Press, Tokyo, pp 448-484

Timmerman P (1981) Vulnerability, resilience and the collapse of society. Environmental monograph No. 1. University of Toronto, Canada

UNDRO (1980) Natural disasters and vulnerability analysis, report of experts group meeting of 9-12 July 1979. UNDRO, Geneva

UNISDR (2004) Living with risk. UNISDR, Geneva

Watson RT, Zinyoera MC, Moss RH (1998) The regional impacts of climate change: an assessment of vulnerability, a special report of IPCC working group II. Cambridge University Press, Cambridge

Wilbanks T, Lankao PR, Bao M, Berkhout F, Cairncross S (2007) Industry, settlement and society. In: Parry M et al (eds) Climate change 2007: impacts, adaptation and vulnerability, contribution of working group II to the fourth assessment report of the intergovernmental panel on climate change. Cambridge University Press, Cambridge, pp 357-390

Yohe G, Richard S, Tol J (2002) Indicators for social and economic coping capacity - moving toward a working definition of adaptive capacity. Glob Environ Change 12:25-40

\section{Publisher's Note}

Springer Nature remains neutral with regard to jurisdictional claims in published maps and institutional affiliations.

\section{Submit your manuscript to a SpringerOpen ${ }^{\odot}$ journal and benefit from:}

- Convenient online submission

- Rigorous peer review

- Open access: articles freely available online

- High visibility within the field

- Retaining the copyright to your article 